\title{
Effect of Intergeneric Pollen on Induction of Parthenocarpy in Watermelon (Citrullus lanatus Thunb.)
}

\author{
V. Sravani*, P. Ashok, K. Sasikala and B. Ramesh Babu
}

Department of vegetable science, College of Horticulture, Dr. YSR Horticultural University, Venkataramannagudem, Andhrapradesh-534101, India

*Corresponding author

\section{A B S T R A C T}

\section{Key words}

Intergeneric pollen, Parthenocarpy, Watermelon, Bottle gourd pollen

Article Info

Accepted:

10 November 2018

Available Online:

10 December 2018
A field experiment was carried out during Rabi 2016 at College of Horticulture, Dr. Y.S.R. Horticultural University, Venkataramannagudem (A.P) to study the effect of intergeneric pollen on induction of parthenocarpy in watermelon. Among the intergeneric pollen studied, bottle gourd pollen was successfully induced parthenocarpy followed by bitter gourd pollen. However, minimum number of empty seeds (37.20) was recorded with ash gourd pollen. The lowest seed weight per fruit $(1.60 \mathrm{~g})$ was observed with bottle gourd pollen whereas maximum seed weight was recorded with control $(17.99 \mathrm{~g})$. The maximum fruit set percentage $(49.26 \%)$, number of fruits per plant (1.56), average fruit weight (1.74 $\mathrm{kg}$ ), yield per plant $(4.75 \mathrm{~kg})$ were observed when female flowers of watermelon were pollinated with bottle gourd pollen.

\section{Introduction}

Watermelon (Citrullus lanatus Thunb.) also known as Tarbuj (Hindi), Palmpanna (Tamil), Kalingarakaya (Telugu). It is a trailing vine, monoecious and belongs to Cucurbitaceae family. It is originated from Southern Africa. Excessive seed number in watermelon fruit is fast becoming unacceptable in international markets. The seedless watermelon cultivars are in high demand by consumers not only because of seedlessness but also because they are sweeter than the fruits from seeded cultivars. Terada and Masuda (1938) showed that seedless watermelon could be produced by artificially induced parthenocarpy. In the distant past, seedless watermelons are produced by a triploid technique by which diploid pollen (male parent) is used to pollinate pistillate flowers of tetraploid watermelon (Kihara, 1951). Sugiyama and Morishita (2000) developed a method for producing seedless watermelon in diploid plants using soft-X-irradiated pollen of intergeneric pollen. The reason behind this approach was to prevent the penetration of normal pollen by pollinating with intergeneric pollen before anthesis of pistillate watermelon flowers. Hence, the present experiment was undertaken to study the induction of parthenocarpy through intergeneric pollen in watermelon. 


\section{Material and Methods}

The experiment was laid out in Randomized Block Design with three replications. The experiment consisted of different intergeneric pollen $\left(T_{1}-\right.$ Bottle gourd pollen, $T_{2}-$ Bitter gourd pollen, $\mathrm{T}_{3}$ - Pointed gourd pollen, $\mathrm{T}_{4}$ Ash gourd pollen, $\mathrm{T}_{5}-$ Bottle gourd + Bitter gourd pollen, $\mathrm{T}_{6}-$ Bottle gourd + Ash gourd pollen, $\mathrm{T}_{7}-$ Bottle gourd + Pointed gourd pollen and $\mathrm{T}_{8}$ - Control). The healthy and disease free seeds were sown in black poly bags of $10 \times 8 \mathrm{~cm}$ size filled with well mixed farm yard manure. The seedlings obtained from nursery were planted in the plots at a spacing of $2.0 \mathrm{~m} \times 0.6 \mathrm{~m}$ at a depth of $2-3 \mathrm{~cm}$. The pollinizer plants i.e., bottle gourd, bitter gourd, pointed gourd, ash gourd were grown adjacent to the experimental field for artificial pollination. The male flowers were bagged with butter paper covers before collection of pollen from male flowers for pollination to avoid contamination of foreign pollen. The female flowers of watermelon are also bagged with butter paper covers. Next day morning the pollen were collected from the bagged flowers and immediately pollinated on watermelon flowers as per the treatment. The pollen were applied with brush gently on the stigma after pollination, flowers were bagged. The data on fruit characters, parthenocarpy and yield characters were recorded and analysed statistically by using OPSTAT software.

\section{Results and Discussion}

\section{Yield attributes}

\section{Days taken from flower to fruit formation}

Data recorded on days taken from flower to fruit formation with different types of intergeneric pollen was found to be non significant (Table 1).

\section{Percent fruit set}

The percent fruit set was significantly influenced by different intergeneric pollen (Table 1). The data indicated that bottle gourd pollen alone recorded the maximum fruit set percentage $(49.26 \%)$ followed by combination with bottle gourd + bitter gourd pollen which was found to be at par with the bitter gourd pollen. However, the lowest fruit set $(22.86 \%)$ was recorded in bottle gourd + pointed gourd pollen. These results were in accordance with the work done by Sugiyama et al., (2014), Sugiyama and Morishita (2000) in watermelon.

\section{Number of fruits per plant}

Maximum number of fruits per plant was recorded with control (3.05) followed by bottle gourd pollen alone and in combination with bottle gourd + bitter gourd pollen (Table 1). The lowest number of fruits per plant (0.90) was recorded when pointed gourd pollen was used. Data recorded on percent fruit set and number of fruits per plant has indicated that bottle gourd and bitter gourd pollen stimulated the fruit set in watermelon. Maximum flower drop was observed, when watermelon flowers pollinated with bottle gourd + pointed gourd pollen which effected the percent fruit set.

\section{Number of deformed fruits}

The number of deformed fruits was significantly influenced by different intergeneric pollen. Highest number of deformed fruits (3.33) was observed when flowers were pollinated with bottle gourd pollen (Table 1). Lowest number of deformed fruits was observed when bitter gourd pollen, bottle gourd + bitter gourd pollen and watermelon pollen was used for pollination. Yamane et al., (2010) hypothesized that deformation of fruit was related to the 
inability of bottle gourd pollen to reach the lower part of the ovary which obstructs hormonal secretion results in deformed fruits. These results were in conformity with Sugiyama et al., (2014) in watermelon.

\section{Average fruit weight}

The effect of different intergeneric pollen on average fruit weight found to be significant. Among intergeneric pollen used, maximum fruit weight of $1.74 \mathrm{~kg}$ was observed in treatment where bottle gourd pollen was used for pollination. The lowest fruit weight (1.07 $\mathrm{kg}$ ) was observed in flowers pollinated with pointed gourd pollen. Maximum fruit weight $(1.85 \mathrm{~kg})$ was observed in control followed by bottle gourd pollen.

Table.1 Effect of intergeneric pollen and its combination on fruit characters

\begin{tabular}{|l|c|c|c|c|}
\hline Treatments & $\begin{array}{c}\text { Days taken } \\
\text { from flower to } \\
\text { fruit } \\
\text { formation }\end{array}$ & $\begin{array}{c}\text { Percent } \\
\text { fruit set } \\
(\%)\end{array}$ & $\begin{array}{c}\text { Number } \\
\text { of fruits } \\
\text { per plant }\end{array}$ & $\begin{array}{c}\text { Number of } \\
\text { deformed } \\
\text { fruits }\end{array}$ \\
\hline T1 : Bottle gourd pollen & 4.33 & 49.26 & 1.56 & 3.33 \\
\hline T2 : Bitter gourd pollen & 5.66 & 40.80 & 1.21 & 0 \\
\hline T3 : Pointed gourd pollen & 5.33 & 29.20 & 0.90 & 0.33 \\
\hline T4 : Ash gourd pollen & 6.00 & 26.70 & 1.04 & 1.33 \\
\hline T5 : Bottle gourd + Bitter gourd pollen & 5.33 & 41.16 & 1.52 & 0 \\
\hline T6 : Bottle gourd + Ash gourd pollen & 4.66 & 23.33 & 1.18 & 2.00 \\
\hline T7 : Bottle gourd + Pointed gourd pollen & 6.00 & 22.86 & 0.94 & 0.33 \\
\hline T8 : Control & 4.00 & 74.60 & 3.05 & 0 \\
\hline SE(m) \pm & 0.57 & 1.57 & 0.06 & 0.31 \\
\hline CD at 5\% & N.S & 4.82 & 0.19 & 0.95 \\
\hline CV $(\%)$ & 19.35 & 7.08 & 7.87 & 58.91 \\
\hline
\end{tabular}

Table.2 Effect of interegeneric pollen on induction of parthenocarpy

\begin{tabular}{|l|c|c|c|}
\hline Treatments & $\begin{array}{c}\text { Number of } \\
\text { apomictic } \\
\text { seeds/ fruit }\end{array}$ & $\begin{array}{c}\text { Number of } \\
\text { empty seeds/ } \\
\text { fruit }\end{array}$ & $\begin{array}{c}\text { Yield/ } \\
\text { plant } \\
(\mathrm{kg})\end{array}$ \\
\hline T1 : Bottle gourd pollen & 0.00 & 58.96 & 4.75 \\
\hline T2 : Bitter gourd pollen & 70.40 & 40.96 & 3.81 \\
\hline T3 : Pointed gourd pollen & 114.53 & 39.96 & 3.43 \\
\hline T4 : Ash gourd pollen & 77.43 & 37.20 & 3.80 \\
\hline T5 : Bottle gourd + Bitter gourd pollen & 112.06 & 47.40 & 3.99 \\
\hline T6 : Bottle gourd + Ash gourd pollen & 168.73 & 61.50 & 4.12 \\
\hline T7 : Bottle gourd + Pointed gourd pollen & 186.06 & 60.50 & 4.27 \\
\hline T8 : Control & 268.50 & 77.53 & 5.84 \\
\hline SE $(m) \pm$ & 3.26 & 2.29 & 0.13 \\
\hline CD at 5\% & 9.98 & 7.03 & 0.39 \\
\hline CV $(\%)$ & 4.52 & 7.5 & 5.27 \\
\hline
\end{tabular}


Fig.1 Effect of intergeneric pollen on seed weight $(\mathrm{g})$ in parthenocarpic fruit

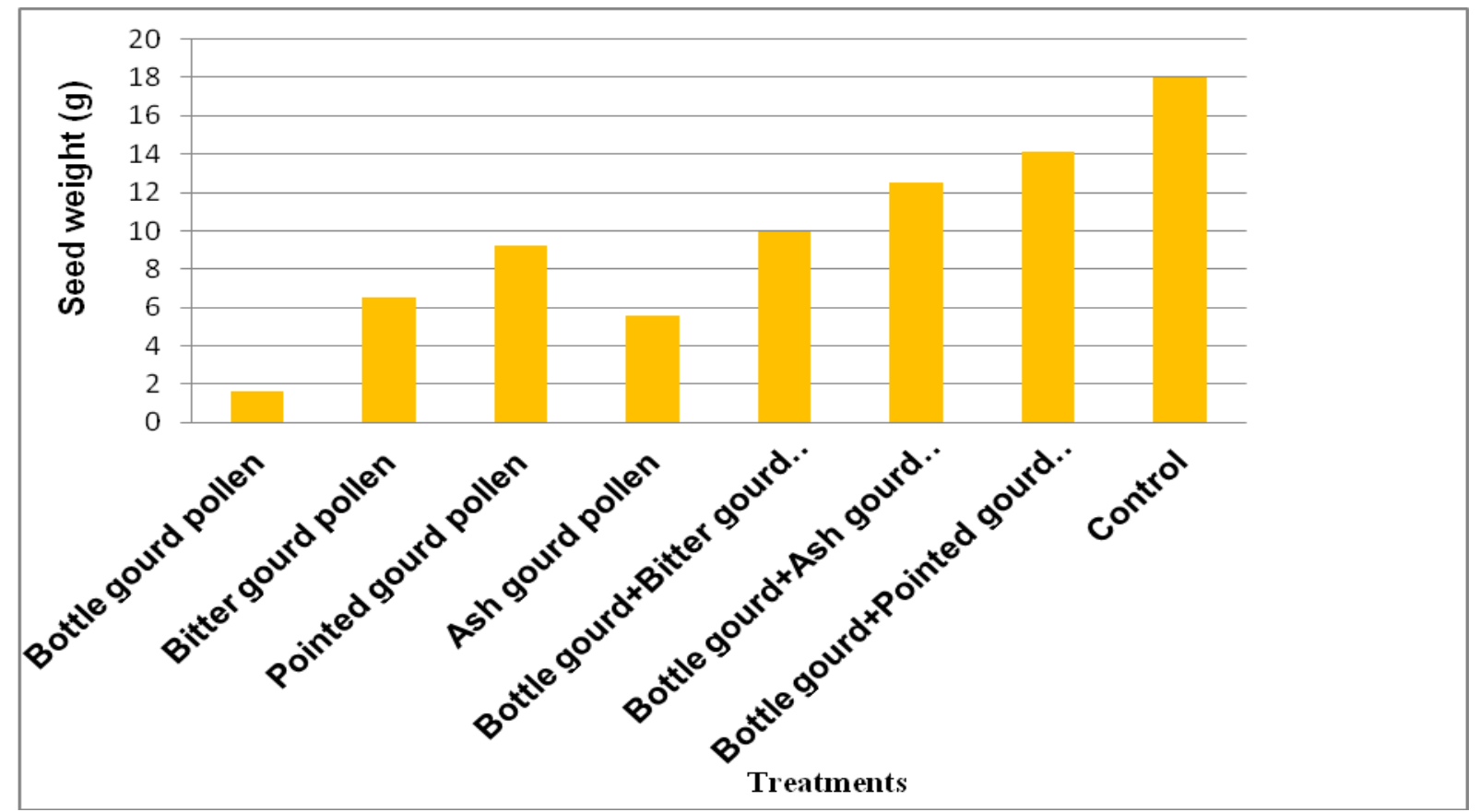

Fig.2 Effect of intergeneric pollen on average fruit weight $(\mathrm{kg})$ of parthenocarpic fruit

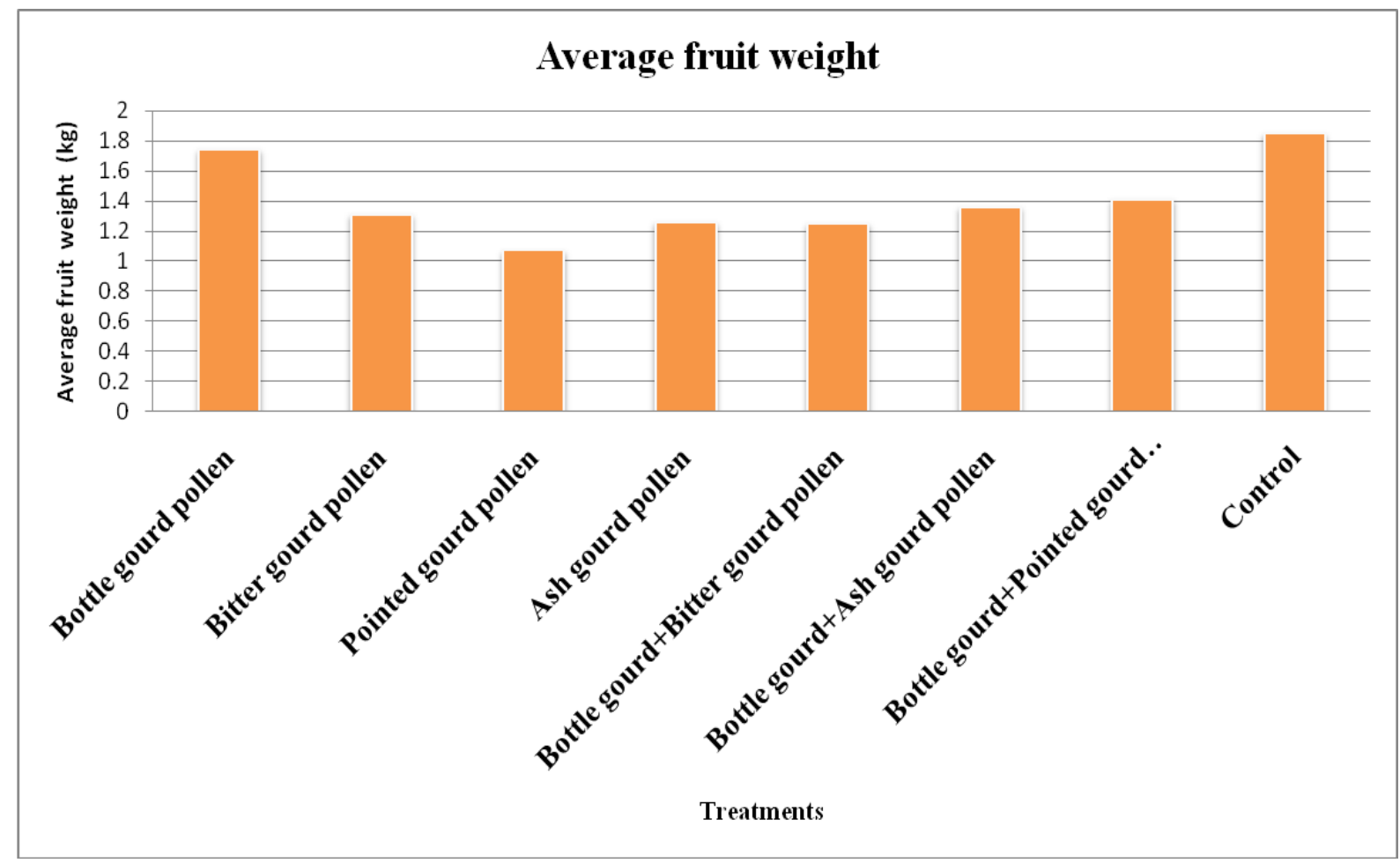


Plate.1 Effect of intergeneric pollen on induction of parthenocarpy

Bottle gourd pollen

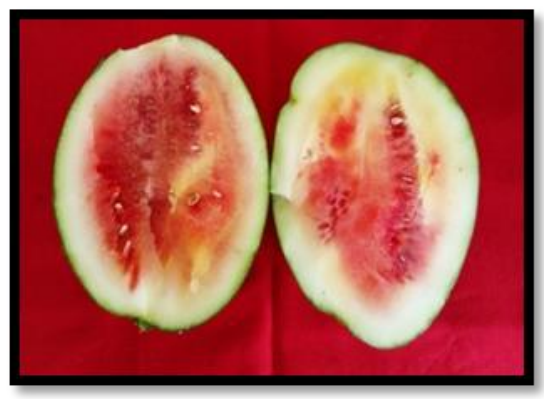

Bottle gourd + Bitter gourd pollen

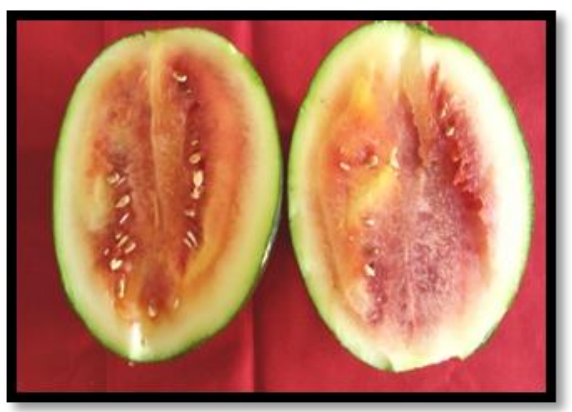

Control

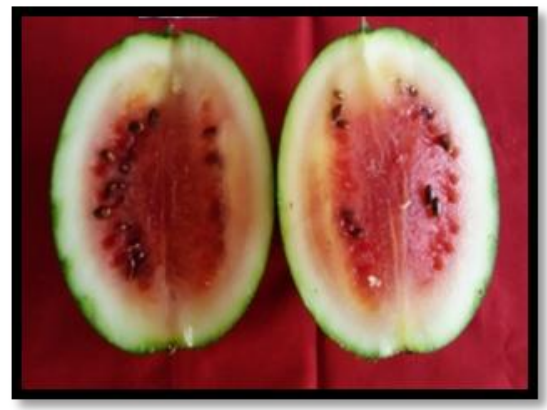

Number of normal seeds and apomictic seeds per fruit

The parthenocarpy was observed in the fruits when bottle gourd pollen was used for pollination. Whereas more number of apomictic seeds (186.06) were observed with bottle gourd + pointed gourd pollen (Table 2 ). The parthenocarpy observed with bottle gourd pollen might be due to the inability of bottle gourd pollen to fertilize the watermelon ovaries soon after pollination. Sugiyama et al., (2014) envisaged that, induction of parthenocarpy in watermelon by pollination with bottle gourd pollen is stimulative parthenocarpy which is caused by pollen grain or pollen tube growth hormones (Yasuda, 1934 and Gustafson, 1937). The seeds are formed by the intergeneric pollen was might be due to apomixis.
Number of empty seeds or papery seeds per fruit

The minimum number of empty seeds were recorded with the application of ash gourd pollen (37.20) followed by the flowers pollinated with bottle gourd + ash gourd pollen (61.50) and bottle gourd + pointed gourd pollen (60.50) (Plate 1 and Table 2). These results are in conformity with Sugiyama et al., (2014) in watermelon.

\section{Yield per plant}

Yield per plant found was found to be significantly influenced by the different intergeneric pollen. Yield of $4.75 \mathrm{~kg}$ per plant was observed in treatment where bottle gourd pollen was used for pollination. Obviously maximum yield $(5.84 \mathrm{~kg})$ was recorded in control. Lowest yield $(3.43 \mathrm{~kg})$ was recorded 
in treatment where pointed gourd pollen was used for pollination.

\section{Total seed weight per fruit}

The lowest seed weight per fruit (1.60 gm) was recorded where bottle gourd pollen was used as intergeneric pollen (Fig. 1). Highest seed weight per fruit was recorded in control $(17.99 \mathrm{gm})$ followed by flowers pollinated with bottle gourd + pointed gourd pollen (14.12 gm). Lowest seed weight was observed in fruits pollinated by bottle gourd pollen due to less number of seeds or papery seeds. Bottle gourd pollen helps in induction of parthenocarpy in watermelon.

\section{Acknowledgment}

I wish to express my sincere gratitude to Dr. P. Ashok, Scientist (Horticulture), AICRP on tuber crops, Andhra Pradesh for providing an opportunity to do my project work in Dr. Y.S.R. Horticultural University, Andhra Pradesh during the year 2016.

\section{References}

Gustafson, F. G. 1937. Parthenocarpy induced by pollen extracts. Am. J. Botany., 24,
$102-107$.

Kihara, H. 1951. Triploid watermelon. Proc. Am. Soc. Hortic. Sci., 58, 217-30.

Sugiyama, K., K. Daisuk and M. Takato. 2014. Induction of parthenocarpic fruit set in watermelon by pollination with bottle gourd (Lagenaria siceraria (Molina) Standl.) pollen. Sci. Hortic. $171,1-5$.

Sugiyama, K. and M. Morishita. 2000. Production of seedless watermelon using soft-X-irradiated pollen. J. Jpn. Soc. Hortic. Sci., 69 (6): 684-89.

Terada, A. and T. D. Masuda. 1938. Colchicine induced polyploidy in watermelon. Forest Sci., 7, 314-19.

Yamane, S., T. Nishino, Y. Tanimura, T. Ogata, K. Hamada and K. Sugiyama. 2010. Effect of fertilization status on the fruit character in seedless watermelon fruit produced by pollination with soft$\mathrm{X}$-irradiated pollen. Hortic. Res. Japan. 9 (2): 166.

Yasuda, S. 1934. The second report on the behavior of the pollen tubes in the production of seedless fruits caused by interspecific pollination. Jpn. J. Genet., $9,118-124$.

\section{How to cite this article:}

Sravani, V., P. Ashok, K. Sasikala and Ramesh Babu, B. 2018. Effect of Intergeneric Pollen on Induction of Parthenocarpy in Watermelon (Citrullus lanatus Thunb.). Int.J.Curr.Microbiol.App.Sci. 7(12): 890-895. doi: https://doi.org/10.20546/ijcmas.2018.712.111 